University of Wollongong

Research Online

Faculty of Social Sciences - Papers (Archive) Faculty of Arts, Social Sciences \& Humanities

2018

Pram mobilities: affordances and atmospheres that assemble childhood and motherhood on-the-move

Susannah Clement

University of Wollongong, sc527@uowmail.edu.au

Gordon R. Waitt

University of Wollongong, gwaitt@uow.edu.au

Follow this and additional works at: https://ro.uow.edu.au/sspapers

Part of the Education Commons, and the Social and Behavioral Sciences Commons

Research Online is the open access institutional repository for the University of Wollongong. For further information contact the UOW Library: research-pubs@uow.edu.au 


\title{
Pram mobilities: affordances and atmospheres that assemble childhood and motherhood on-the-move
}

\begin{abstract}
The child-friendly city advocates for children's 'right to the city'. Much of this advocacy focuses on the independent child, with little attention paid to the accompanied experiences of younger children, such as those travelling in prams. This paper draws on a material feminist perspective to help address this gap. We offer the concept of mother-child-pram assemblage to bring to the fore the corporeal dimensions of everyday pram journeys. By analysing sensory ethnographic materials collected with mothers and young children living in Wollongong, Australia, this paper highlights how the 'affective affordances' and 'affective atmospheres' of pram mobilities shape urban experience by reference to how motherhood and childhood are achieved on-the-move. We conclude with policy-relevant insights for the child-friendly city.

\section{Disciplines \\ Education | Social and Behavioral Sciences}

\section{Publication Details}

Clement, S. \& Waitt, G. (2018). Pram mobilities: affordances and atmospheres that assemble childhood and motherhood on-the-move. Children's Geographies, 16 (3), 252-265.
\end{abstract}




\title{
Pram mobilities: affordances and atmospheres that assemble childhood and motherhood on-the-move
}

\author{
Susannah Clement, Gordon Waitt
}

Australian Centre for Cultural Environmental Research, School of Geography and Sustainable Communities, University of Wollongong, NSW, Australia, 2522

\begin{abstract}
The child-friendly city advocates for children's 'right to the city'. Much of this advocacy focuses on the independent child, with little attention paid to the accompanied experiences of younger children, such as those travelling in prams. This paper draws on a material feminist perspective to help address this gap. We offer the concept of mother-child-pram assemblage to bring to the fore the corporeal dimensions of everyday pram journeys. By analysing sensory ethnographic materials collected with mothers and young children living in Wollongong, Australia, this paper highlights how the 'affective affordances' and 'affective atmospheres' of pram mobilities shape urban experience by reference to how motherhood and childhood are achieved on-the-move. We conclude with policy-relevant insights for the childfriendly city.
\end{abstract}

Keywords: walking; sensory ethnography; child-friendly cities; 'right to the city'; affect; corporeal 


\section{Pram mobilities and the city}

This paper explores the role of the pram $^{1}$ in constituting childhood and motherhood to help rethink 'child-friendly city' policy. World-wide policy concern for the child-friendly city is institutionalised through UNICEF's Child Friendly City Initiative (CFCI). Whilst

underpinned by the UN Convention on the Rights of the Child (1989), this initiative also taps into long standing 'right to the city' debates (Fenster 2005; Harvey 2008; Whitzman et al. 2010; Middleton 2016; Cushing and van Vliet 2017). The CFCI provides guidelines for municipal authorities to help improve children's access, participation and governance in urban life (UNICEF 2004; Gleeson and Sipe 2006). Importantly, as Woolcock et al. (2010) highlight, addressing children's right to the city through the CFCI requires more than just designing play spaces for children, but involves shifting the material and social constraints placed on their everyday lives in a broader way.

Over the last three decades, a key starting point for those advocating for children's right to the city is research that documents declining independent child mobility in the Global North (Hillman et al. 1990; Carver, Watson, et al. 2013; Schoeppe et al. 2016). The rise of the accompanied child is partly attributed to the changing cultures of parenting (Karsten 2005; Talbot 2013; Woolley and Griffin 2015), increased auto-mobility (McDonald and Aalborg 2009; Carver, Timperio, et al. 2013) and unwalkable cities (Kytta 2004; Villanueva et al. 2014). Much of this work orients children's independent mobility as necessary in order to achieve the child-friendly city (Collins and Freeman 2005; Whitzman et al. 2010). However, recent scholarship questions the focus on children's independent mobility raising three main critiques. First, insufficient attention is paid to how children often journey with parents,

\footnotetext{
${ }^{1}$ We use the term 'pram', short for perambulator, to refer broadly to a range of mobility technologies for young children including strollers, buggies and pushchairs. Many participants used these terms interchangeably. Hence, whilst we are alert to the technical differences between names (pram denotes a device for an infant whilst stroller more commonly describes a device used by toddlers and preschool aged children), we argue that what the device can do and how it is used, rather than what it is called, are more important questions to consider.
} 
grandparents and friends (Mikkelsen and Christensen 2009; Holdsworth 2013). Second, the transport needs of younger children (those aged under 4 years of age) are overlooked or, at best, considered as incidental to those of adults accompanying them (Grant-Smith et al. 2012). And third, a humanist legacy frames the notion of independent mobility; as Nansen et al. (2015) remind us that, mobility is never independent, but always accompanied, influenced and negotiated alongside an array of (non)human actors, including the mode of transport.

This paper addresses these critiques by shifting the analytical gaze to the recent embodied and affective geographies of mobilities. Absent from this research is a consideration of the everyday lived experiences of children who journey with prams. This paper proceeds from the starting point that subjectivities and spaces of mobility are relationally constituted. Hence in this paper we explore how children and mothers (who in our research most often accompanied children with prams) experience pram mobility. To do so we ask, how is motherhood, childhood and the city felt and constituted by those who journey with prams?

The literature on prams and parenting is substantial. For example, McLaren and Parusel (2015) on parental mobility care; Currie and Develin (2002) on post-natal depression; Birken et al. (2015) on the usefulness of pram mobility; and Cortes-Morales and Christensen (2014) on mobile mothering space. Much of the literature focuses on the experiences of mothers journeying with prams. Work from feminist geography illustrates how pram mobility not only extends but also restricts a mother's capacity to go places on-foot with children in the city. Feminist scholar, Linda McDowell $(1993,166)$ captures this mobility 'burden' succinctly, writing: 'the stolid figures of urban commuters were never encumbered by a baby, a stroller and the week's shopping.' Feminist scholarship highlights how the gendered and classed politics of care sit alongside mobility (Hillman et al. 1976; MATRIX 1984; Tivers 1985; Bostock 2001; Fritze 2007; Grant-Smith et al. 2012). This work emphasised how the 
challenge of pram mobility become even more pronounced for mothers from disadvantaged backgrounds, particularly when travelling on public transport.

Yet, within such feminist scholarship, the perspectives of children themselves are usually absent. Feminist and children's geographers have been slow to engage children in their research on prams. We argue that the absence of children's voices in pram mobility research is a significant knowledge gap given repeated calls to unsettle adult-centric ways of viewing the world (Holloway and Valentine 1999; Horton and Kraftl 2005; Horton et al. 2008; Tisdall and Punch 2012).

To better understand the subjectivities and spaces of pram mobility for mothers and children the paper is structured in five parts. First, after Boyer and Spinney (2016), we outline a material feminist approach to investigate the processes of becoming a 'mother-child-pram assemblage' in order to achieve mobility. This approach enables us to rethink the right to the city as co-constituted through the relationships between spaces, prams, routines, routes, subjectivities and (non)humans encountered when out and about. To help further interpret the embodied and performative dimensions of pram mobilities we draw on the notions of 'affective affordance' (Jensen et al. 2015) and 'affective atmospheres' (McCormack 2008; Anderson 2009). Second, we discuss our walking sensory ethnography conducted in Wollongong, New South Wales, Australia. This method allowed us to document the ways in which pram mobility might produce bodies and spaces with certain capacities, emotions and affects. Third, we outline how the affective affordances of pram mobility work to modify the bodily capacity to act and become mother and child on-the-move somewhere. Fourth, to shed light on the constitution of childhood and motherhood on-the-move we turn to the notion of affective atmosphere in order to interpret the choreographies of bodily interactions, connections and disruptions of pram mobilities. Finally, we invite further scholarship to engage with the diverse corporealities of pram mobility to explore how policy-makers might 
achieve child-friendly cities. We encourage future research to consider how the 'right to the city' is felt for a range of different bodies, including older children, fathers, grandparents and others in loco parentis.

\section{Mother-child-pram assemblages}

Assemblage thinking conceives mobility as the outcome of a process, rather than the movement from point A to point B. Following Deleuze and Guattarri's (1987) concept of assemblage, we understand how individual and collective subjectivities, alongside mobility practices become relatively enduring over time and space via the interaction, intertwining energies and flows that establish connections and disconnections between norms, things and bodily routines. In this way, motherhood and childhood may be conceived as a provisional assemblage or working arrangement which 'in its multiplicity necessarily acts on semiotic flows, material flows and social flows simultaneously' (Deleuze and Guattari 1987, 22).

Extending Boyer and Spinney's (2016) work on the materialities of mobile mothering, we offer the idea of 'mother-child-pram assemblage' as a way to attend to how things come together in a provisional working arrangement that functions as mechanism of inclusion and exclusion to achieve a particular kind of mobility. In the familial household, working arrangements of pram mobility are provisional in two senses: (i) they involve routinized practices and routes that are always subject to revision, change or innovation; and, (ii) they are about making something available (exercise, fresh-air, transport, relaxation or company) (Boyer and Spinney 2016). Pram mobility is subjected to change not only because of the weather, transport services or technologies but also in the context of changing social norms of mothering. For example, exercising with a specific branded pram is promoted as a hallmark of 'good' mothering. Deleuze and Guattari's (1987) notion of assemblage insists that pram 
mobility is always more than meanings. Therefore, attention turns to processes in which the pram works alongside emotions, affect, ideas, routines, weather, sidewalks, traffic and children to enable people to exercise and achieve feeling fit. Hence, the pram mobility achieved within this working arrangement or assemblage becomes taken-for-granted by the way it comprises the non-human and human interactions and connections that are always shifting to achieve a specific goal.

Understanding spaces and subjectivities of pram mobilities via this approach is helpful because it facilitates rethinking journey-making with children through the emotional and affective potentialities of bodies and the material affordance of prams - including their light weight, solid-feel, manoeuvrable, storable, portable and flexible qualities. After Ahmed (2004), we think of emotion and affect as working together in and through bodies and spaces to connect people with place and create certain vibes or moods, rather than separating out emotion as an expression of individual subjective identity, or consider affect as precognitive bodily intensity or capacity to act. The concept of affordance, as coined by Gibson (1986, 140 ), refers to how the perceptual properties of an object can provide 'benefit or injury' to the body. Transporting children in a pram to achieve mobility might both increase and decrease the experience of encumbrance when moving through the city. As Michael $(2000,112)$ reminds us: 'the affordances of any technology are always, at least potentially ambiguous'. The concept of 'affective affordances' (Jensen et al. 2015) extends this thinking, opening up the understandings of how more-than-human actants might support or work against pram mobility and the becoming of a 'good' mother, father, child or family. The affective affordances of a pram are said to mediate the affective and emotional relationships between human and non-human bodies, increasing or decreasing their bodily capacity to act. Echoing Deleuze and Guattari's $(1987,256)$ discussion of affect as 'becomings', we understand how bodies are drawn together and apart by their ability to affect and be affected. Furthermore, we 
understand that the affective affordances of pram mobilities help make sense of the working arrangement known as motherhood or childhood.

Alongside affective affordances, there is an important spatial dimension to the mobility achieved by mother-child-pram assemblages. After Bissell $(2010,273)$, affect is 'the relational potential for things to act or change in a particular space'. Place and certain routes, then, are understood to offer a distinctive propensity, a pull, force or energy that may, or may not, emerge in a specific space to generate actions, events and emotions, such as a heightened or reduced capacity to feel relaxed, energised or exhausted. McCormack $(2008,413)$ articulates the idea of 'affective atmosphere' as 'something distributed yet palpable, a quality of environmental immersion that registers in and through sensing bodies whilst also remaining diffuse, in the air, ethereal'. Or as Anderson $(2009,78)$ suggests, 'affective atmospheres are a class of experience that occur before and alongside the formation of subjectivity, across human and nonhuman materialities, and in-between subject/object distinctions' (emphasis in original). Affective atmospheres are forceful moments that modulate a body's capacities to affect and be affected in specific places. This is, alongside the discourses of mothering or childhood; it is the sensed and intangible qualities of routes and routines (sound, smell, sight, velocity, frictions, pace, rhythm) registered on the mobile body as affect or moments of intensity that may be articulated as an emotion. These affects are central to how people inhabit those spaces of pram mobility. As such we argue that the subjectivities of mother and child emerge through the ebb and flow of the affective atmospheres to generate specific actions, emotions and understandings of places as either pram-friendly or not.

\section{Walking sensory ethnographies}


This paper draws on the analysis of empirical materials gathered during 2015 from a walking sensory ethnography conducted with sixteen families in Wollongong, New South Wales, Australia. Wollongong is a regional city with a population of approximately 205,000, situated on the east coast 80 kilometres south of Sydney. We focus on a subset of participants; eight mothers and ten children (aged from three months to four years) who make regular pramjourneys. Like many municipal authorities in the Global North, Wollongong City Council (WCC) is a candidate city for UNICEF's CFCI. In Wollongong, the concept of the childfriendly city fulfils an important political and moral objective that involves: 'keeping children and young people at the centre of the city's vision for development. We believe that a city that is good for children is a city that is good for everyone' (WCC 2015). Furthermore, WCC illustrates how UNICEF's CFCI framework plays out through the recent adoption of the Play Wollongong Strategy 2014-2024. The strategy was designed following a children-led consultation process and highlights the importance of children's spaces and mobility. Yet, this strategy focuses on play-based forms of movement that typify older, 'independent' children's journeys.

Participants were recruited through personal networks, a newspaper article, and flyers distributed at preschools, and children's play and sports centres. Adult participants who journeyed with prams were usually mothers aged between 30 and 50-something from ethnically diverse and relatively affluent, highly educated households. Only two fathers walked with prams, and mothers were present on both journeys. This gender imbalance illustrates the cultural norms that continue to shape heteropatriarchal middle-class nuclear family life in Australia that positions childcare, and the mobility challenges it brings, as women's work (Dowling 2000; Waitt et al. 2016). Like Barker (2011), in our study, we found that women did most of the work of journeying with children transported in prams. 
Furthermore, it was primarily women and their children who gave up their time to participate in our walking sensory ethnography.

After Sarah Pink $(2007 ; 2009)$, sensory ethnography is a term for an array of qualitative research methods that aim to analyse embodied ways of knowing. Our walking sensory ethnography consisted of two stages. Mindful of Horton et al.'s (2014) concern around adultcentred understandings of mobility, the first stage involved drawing activities for children and semi-structured interviews for adults. These were normally conducted in participants' homes. Following Greig et al. (2007), children over the age of three were invited to draw a picture of 'You and your family going for a walk' to facilitate discussion. Interview questions were focused to explore participants' everyday pedestrian mobility and their walking life narratives.

The second stage involved video methods. As Spinney $(2009,828)$ outlines, the benefits of video methods are 'that the researcher can begin to explore how people use space and their bodies, how people interact with space, understand where and how they look, and ultimately gain a far more nuanced idea of how participants derive meanings through movement.' The aim of video methods was to give insights to the processes by which participants' mobile prammed bodies achieved a sense of self and place. Video methods provided a way to discern how city spaces were felt as pram-friendly or not; not through discourses alone but embodied in routine practices and the potentiality of place. Each household was provided with a small, lightweight video camera (Go-Pro) that could be attached to clothing, bodies or prams, and an audio-recorder on a lanyard. Participants were invited to video/audio record at least four walks they did together over a fortnight, with a researcher attending one of these walks. To help move beyond representational registers of thought, while viewing each video, attention was given to mapping the densities and textures of energies as they connect and interact between bodies. Notes were written about each of the video/audio recordings paying attention 
to moments of affective and emotional intensity indicated by tone of voice or bodily gestures. These notes provided the basis for a follow-up conversation where participants watched, listened and reflected on each moment selected by the researcher (Pink 2007; 2009).

Following Pink (2009), we approach sensory ethnography with the view that knowledge is the co-production between researchers and participants. As Pink $(2009,120)$ writes, 'creating an analysis is not an activity that is itself isolated from 'experience' or from the researcher's embodied knowing.' As such, our own experiences of becoming mobile with young children shaped the interviews and analysis. At the same time, we remain wary of Salamon's (2015) concern about misinterpreting young children's experiences by imposing parents' or researchers' own interpretations of events and experiences. Our analysis is guided by Duffy et al.'s (2016) discussion of emotional and affective mapping, which brings together five interconnected registers of discourses (motherhood, childhood), materiality (including the body of the researcher and recording devices), the spatial, movement (pace, rhythm, speed), as well as affect and emotion. This approach led us to frame our interpretation through the notions of 'affective affordances' and 'affective atmospheres' to offer insights to how motherhood and childhood emerge through the spaces of pram mobilities.

\section{Affective affordances of pram mobilities}

\section{Controlling bodies}

Mayra: Yeah, [I'm] always worried, that's why I all the time use [the] pram; just to keep her [Aiyana (age four)] [close] ...

Mayra is a full-time university student from Bangladesh in her early 30s. Mayra is married; however, her husband lives in Bangladesh. Day-to-day she is the sole parent for her four- 
year-old daughter, Aiyana. Mayra does not drive; therefore, she travels on-foot or uses public busses. Mayra describes how car dependent Wollongong is not child-friendly. In Mayra's words, she is 'always worried'. Hence, her use of a lightweight four-wheeled foldable pram affords less stressful journeys with Aiyana by immobilising her daughter's body to keep her close. Mayra highlights Talbot's (2013) argument that motherhood is completely bound up in discourses of risk and emotional investment in children's welfare. As McLaren and Parsuel (2015) highlight, prams are important tools for parents to control children's bodies around busy roads and manage this risk. The affordances of the pram to restrain may operate to confirm ideas of 'good' mothers being in control of children's bodies. Simultaneously, the intensity of affective forces, such as physiological stress, is reduced.

Being and becoming an 'in control' mother emerges through specific pram technologies, bodies and their collective affective affordances. For example, Ashleigh, an Anglo-Australian married mother of three in her late 40s, describes how the affordance of her well-worn yet manoeuvrable three-wheeled pram enables her to do mothering-on-the-move:

Ashleigh:... Ummm this stroller is incredibly easy to manoeuvre, so if she's [Milly (age two)] calling out or whatever, I just swing it around and see what she's up to. But if the hood's back like that I can just bend over and see. It's simple... this one is, I got [this one] when Chris [age six] was born, three wheelers are the best ones. I can move it with one finger...

For Ashleigh, the pram's materiality (size and weight) is known through years of practise. In her words, they are felt within her body as 'simple'. When journeys with children lack this manoeuvrability, as Mayra explains, doing mothering-on-the-move becomes more challenging: 
Mayra: When I do walk, I take the pram because; suppose I go this way and she will talk to the opposite side. So, it's totally different, and I have to rush all the time to get her, so you know.

Hence, mothering is more than just 'done'. The doings of mothering are made possible through the habitual interplay of technological, material and bodily specificities.

\section{Carrying bodies and things}

Prams afford mothers increased mobility by reducing the physiological stress and the physical strain of carrying children and items. Mayra explains that alongside keeping her daughter 'safe', another affordance of pram mobility is to carry heavy groceries and tired bodies:

Mayra:... it is really unmanageable without it, so that is why I manage her and I take the stroller and sometimes with the heavy things, with the hood of the stroller I can take like rice and...

Researcher: Oh, you can put things on top, yeah. So, it helps you?

Mayra: Its helps me, and on the other side it she can sit here...... So, a stroller has good side, many many good sides. .... Yeah, and sometimes if she feels sleepy she can sleep at the stroller, in the stroller and on the other side I can buy the things.

The mother-child-pram assemblage is mutable and continually transformed over and through time and space. For Mayra, her daughter's pram is an important device to help her fulfil domestic tasks, such as grocery shopping and future meal preparation. When hooking grocery bags over the handles and stacking large bags of rice on the hood, the mother-child-pram assemblage enables Mayra to do the shopping on-foot with her daughter. The pram becomes 
part-trolley because of its affordance to displace the shopping weight on four wheels, while it provides a seat for Aiyana to be transported.

As Boyer and Spinney $(2016,1120)$ highlight, journeys with young children and mothers often involve more than just pram technologies; prams afforded the bringing along an array of 'baby-detritus'. Bella, an Anglo-Australian married mother of one in her early 30s, exemplifies this, listing the things brought along when journeying with her son, Lachlan (age three), in their four-wheeled pram to the park:

Bella: There are always a set of keys on the pram ... I always take food, water, for him and because this [walk] was longer I took a backpack with a change of clothes for him as well ...... And because we knew it was going to be windy I think I even brought his beanie and jumper.

For Bella, these mundane objects were integral to the performance of maternal identities onthe-move. The routine of packing baby things into the pram is one way she becomes the 'good' mother, prepared for an array of 'different eventualities' (Boyer and Spinney 2016). For mothers, our participants' lived experience illustrates how the pram affords safety, transportation of items and increased mobility.

\section{Changing bodies and cities}

For children, our analysis suggests journeying with, or without a pram, is deeply embedded in understandings of 'childhood' and becoming 'grown-up'. For example, Figure 1 shows some of the participants' anxieties about what prams 'do' to children's bodies. Here we see Sunni, a married, full-time university student from Malaysia in her mid-30s and her daughters, Madi (age four) and Saffi (age six), walking without their pram from home to the nearby pool for swimming lessons. Sunni is worried about the way using her pram position her four-year-old 
daughter, Madi, as a baby. Sunni alerts her daughter to how prammed bodies do not resonate with her understanding of a primary school-aged child. For Madi, the absence of the pram on this journey to swimming lessons is felt by her 'tired legs' as she complains to signal concerns about her mother's care. However, for other four year-olds, the mother-child-pram assemblage not only marks out a pre-school childhood identity, but also subsumes the 'grown-up' aspects of the self. For example, Mayra explains how her daughter, Aiyana, increasingly does not want to sit in her pram, preferring to walk:

Mayra: ...when going to preschool, she says 'Mumma I am growing up, so why you take me in the stroller? The teacher will laugh when seeing the stroller, I'm a big girl.'

Both examples highlight how the relationship between child and pram are attached to experiences of becoming grown-up. Such comments highlight how childhood is coconstituted from human and non-human relationships on journeys to preschool.

The affective affordances of the pram also came up in discussion of how mothers changed younger children's somatic state and mood. For example, Bella reflects on how pram mobility was used to exercise and change her new-born son's sleep patterns when she was on maternity leave:

Bella: For exercise and also I wanted Lachlan to learn to sleep in the pram. So, every day I want him to have a nap in the pram, so he got used to it. ...... and sometimes I'd even go a longer route because I would time it with Lachlan's sleep. 'Okay, well he can sleep for the length of that', rather than interrupt him, let him sleep. You'd interrupt him to get to an appointment. So, I'd just walk so he'll sleep in the pram. 
These findings echo those made by Boyer and Spinney $(2016,1120)$ who underscore the pram's ability to offer mothers a 'short break from the physical and emotional demands of caring for a young baby.' For Bella, pram mobility presented opportunities for 'doing' exercise to condition her own body into a 'healthy' state and to render the city more amenable to mothering by changing her son's somatic state.

The affective affordance of prams was presented in discussion of how prams not only mediate children's moods and somatic state, but also children's imaginations. For example, three year old, Ethan and his mother, Alicia, an Anglo-Australian married mother of two in her early 50s, speaks of the affective affordance of his foldable four-wheeled pram and its attachable plastic rain cover:

Ethan: Ummm when it's raining I need that cover over me when I'm in the stroller. And when I'm playing Oznaughts, it's like I'm in a Gupe.

Alicia [Ethan's mum]: Oh, you can pretend you're inside a Gupe, like the Octonauts. Researcher: What's an Octonaut?

Alicia: The toys he's got, so he can pretend he's like in one of those ship things Researcher: Oh cool

Ethan: And the cover can be the windscreen

\section{Alicia: Like an underwater submarine}

With the rain cover on, Ethan imagines he is an Octonaut, a character from a popular child's animated TV show, travelling in his Gupe (an underwater submarine). The affective transition between human and non-human bodies-on-the-move shifts the way the Ethan experiences the city through becoming 'otherwise' (Woodyer 2012). Ethan's imaginations 
highlights that for children, pram mobility is felt to be productive beyond adult-centric understandings. For children, we argue that the cocooned comfort of pram mobility affords the opening-up of new imaginings, new ways of being, new assemblages and new experiences of the city.

\section{Affective atmospheres of pram mobilities}

\section{Fear, Sociality and Safety}

Participants highlight the point that alongside the affordance of pram mobilities, the possible feeling of journeying with prams was instrumental to route choice. For example, Bella explains how the anticipated affective atmosphere of sociality made through the presence of bodies, prams, traffic, sounds, daylight, weather, and the materiality of pavements and roads, shaped her route choice while mothering with a pram:

Bella: Well, we try to choose more quiet roads and when it was on a main road, we then just went behind each other, rather than parallel. There's a path that runs along the Northern Distributor. I have walked that a few times but I don't ever feel - it's eerie and it's always got dog poo. So, taking your pram through there is a nightmare and then walking, it's just not pleasant.... like because there was no footpath, we went on the road because often we had the two prams. You couldn't do two prams side-by-side anyway. They're too narrow. So yeah, we just walked on the road.

Bella describes how the transmission of visual, olfactory and sonic affects of the mother-child pram assemblage along the too-narrow path next to the Northern Distributor (the busiest northern arterial road in Wollongong) worked towards an affective atmosphere of fear rather than sociality. In contrast, despite the absence of pavements, the mother-child-pram 
assemblage constituted through the potential of 'more quiet' suburban backstreets provided a more conducive affective atmosphere of sociality and safety. Bella's experience highlights the point made by feminist scholars (Gibson-Graham 2006; Boyer and Spinney 2016) that the mobility needs of younger children and mothers are often overlooked in cities where planning is informed by a capitalist imperatives for speed and efficiency that prioritises cars over pedestrians. Yet, while exposed to the risk of slow-moving hard metal bodies of cars, Bella's prammed body feels not vulnerable but energised. As Boyer and Spinney (2016) argue, these practices can be read as a form of resistance to normative encounters with the built environment where participants came to know themselves as mothers. Equally, Bella's pram mobility underscores Jensen et al.'s (2015) point that the affect anticipated travelling particular routes, by car, cycle, train or foot, are strategically used to manage emotions and moods.

\section{Frustration}

The feeling of frustration is also apparent across many participants' spaces of pram mobilities. For example, Figure 2 illustrates how, for Lachlan, sitting in his pram and waiting to cross a road at a red traffic light created intense feelings of frustration, heightened by the absence of passing cars. This example serves to highlight how automobility as the dominant form of transport affects prammed bodies who are often left waiting for their turn to move. Following Fisher $(2002,14)$, frustration is conventionally understood as solely a human achievement and a 'response of the will when it is baffled and unable to achieve its goal.' However, from a material perspective this eruption of frustration can be approached as an affective atmosphere, where different affects emerge through ebbs and flows and the coming together of environments, technologies, bodies and practices. As Bissell (2010) argues, for bodies prepopulated with an anticipation of flow, disruptions may cause annoyance and anxiousness. This affective force of waiting is conveyed by Lachlan's language, tone and 
rhythm of speech. For Bella, this affective force created new capacity to reach out to her son, consoling him through her tone of voice and explanation of waiting in order to avoid danger. Our mapping of the ebb and flow of the affective atmosphere of frustration encouraged us to think through the 'family-friendly' city not as a product of particular objects but as expressive of the affective ties that bind people together.

\section{Playful}

As mothers become mobile with younger children it is striking how they use prams strategically to schedule time, negotiate risks and to mediate their child's moods and energy levels to enhance more playful interactions within cities. Consider the video stills in Figure 3, which feature Alicia and Ethan walking to the train station after visiting a friend. The video shows Ethan walking along a grassy verge talking to himself as he repeatedly picks-up and throws away a palm frond while Alicia slowly walks next to him pushing the pram. Alicia explains:

Alicia: Yes, yes heading back to the station. And Ethan was allowed to walk for some of the way.... if we're not in a hurry, and it's not going to be busy, [walking,] it's just more fun for him.

For Alicia, facilitating moments for her son to play is one way she constitutes motherhood on-the-move. Alicia's quotation also exemplifies how the affective atmospheres that enable her to facilitate play are partly kinetic. On this return journey, there is no traffic to generate anxiety nor timetable or itinerary, which may act to generate anticipated affects of flow that when disrupted can lead to frustration. As a result, the lack of footpath and the friction caused by pushing the pram across the grassy surface is not felt as a hindrance. Instead, playful affects conveyed by smiling faces, held hands, tones of voice and laughter emerge as they momentary halt to look, listen and gather things encountered enroute. This example illustrates 
how urban spaces such as verges become felt as child-friendly through fleeting moments where motherhood and childhood is achieved through play.

\section{Pushing forward}

Our paper illustrates the importance of pram mobilities, and their role in the spatial and temporal organisation of motherhood and childhood in the city. Well established in the feminist literature are arguments that journeying with prams brings to fore mothers' uneven access to the city and is an essential mothering tool used to restrain children's bodies. Yet, less is known about the lived experiences of pram mobilities, and specifically the experiences of those strapped inside prams. We concur with the CFCI that young children should have 'a voice' in urban planning and agree that policy should be infused with the lived experiences of children. Hence, the significance of our paper lies how we bring attention to not only mothers, but also children's experience of pram mobility in Wollongong.

We offer the concept of mother-child-pram assemblage to further progress children's geographies scholarship by exploring how motherhood and childhood is always a relational achievement; an outcome of a process operating across human and non-human actors. To examine pram mobility as the mother-child-pram assemblage, attention was brought to the felt challenges of doing motherhood and childhood on-the-move. Through the concept of affective affordances we explored how the ability of prams to carry children's awake and sleeping bodies and things enabled the becoming of 'good' 'in control' and 'prepared' mothers. For children, prams simultaneously assigned identity values to those seated as 'baby' whilst affording tired legs a comfortable place to rest and the possibility to imagine themselves as otherwise. The concept of affective atmospheres offered valuable insights to how pram mobility was experienced socially and playfully to enhance the capacities of 
bodies to act and be affected. Yet, affective atmospheres were primarily described negatively, including 'frustration' and 'fear'. For example, child participants provided examples of how prammed bodies anticipate flow and constant movement while travelling, and how anger and frustration erupts while waiting to cross roads. At the same time, mothers provided compelling examples of how they modulated affective atmospheres when spaces of car and pram mobility converged. There is politics of mobility invoked by how these women reclaim roads and generate spaces of sociality on-the-move. Hence, it is not simply the lack of pavements that work against the 'right to the city', but the anticipated affective atmospheres of safety that circulate between bodies, prams, surfaces and vehicles to render the city childfriendly or not.

In thinking about who has the 'right to the city' we have shown that it is important to grapple with the corporeal dimensions of mobility. We argue that assemblage thinking offers a productive lens to contribute to this agenda and inform scholarly, policy and popular debate around the child-friendly city. Policy makers need to take seriously that children's movement is always bound up in the interpenetration of social, cultural, material and political entities. Our work points to the importance for child-friendly city policy to better understand how mobilities relate to not only to children but other family members and technologies. Hence, we encourage further scholarship on the mobile spaces of pram mobility to examine how the 'right to the city' is felt for a range of different bodies, including older children, fathers, grandparents and others in loco parentis.

\section{Acknowledgements}

Thank you to all the participants. Thank you to those who have commented on earlier drafts, including two anonymous reviewers, Ian Buchanan, Lance Barry, Rebecca Campbell, Carrie 
Wilkinson and session organisers, discussants and audience members at various conferences (Institute of Australian Geographers Annual Conference 2016, University of Wollongong's Social Sciences HDR Conference 2016 and the Association of American Geographers Annual Meeting 2017). This research has been conducted with the support of the Australian Government Research Training Program Scholarship.

\section{References}

Ahmed, S., 2004. The Cultural Politics of Emotion, Edinburgh: Edinburgh University Press and Routledge.

Anderson, B., 2009. Affective atmospheres. Emotion, Space and Society, 2(2), pp.77-81.

Barker, J., 2011. "Manic Mums" and "Distant Dads"? Gendered geographies of care and the journey to school. Health and Place, 17(2), pp.413-21.

Birken, C. S., Lichtblau, B., Lenton-Brym, T., Tucker, P., Maguire, J. L., Parkin, P. C., and Mahant, S., 2015. Parents' perception of stroller use in young children: a qualitative study. BMC Public Health, 15(1), p.808.

Bissell, D., 2010. Passenger mobilities: Affective atmospheres and the sociality of public transport. Environment and Planning D: Society and Space, 28(2), pp.270-289.

Bostock, L., 2001. Pathways of disadvantage? Walking as a mode of transport among lowincome mothers. Health and Social Care in the Community, 9(1), pp.11-18.

Boyer, K. and Spinney, J., 2016. Motherhood, mobility and materiality: Material entanglements, journey-making and the process of 'becoming mother.' Environment and Planning D: Society and Space, 34(6), pp.1113-1131. 
Carver, A., Timperio, A. and Crawford, D., 2013. Parental chauffeurs: what drives their transport choice? Journal of Transport Geography, 26, pp.72-77.

Carver, A., Watson, B., Shaw, B., and Hillman, M. 2013. A comparison study of children's independent mobility in England and Australia. Children's Geographies, 11(4), pp.461-475.

Collins, D., and Freeman, C. 2005. Creating Child Friendly Cities Symposium, Brisbane, October 2004. New Zealand Geographer, 61, 61-67.

Cortés-Morales, S. and Christensen, P., 2014. Unfolding the Pushchair. Children's Mobilities and Everyday Technologies. Research on Education and Media, 6(2), pp.9-19.

Currie, J.L. and Develin, E., 2002. Stroll your way to well-being: a survey of the perceived benefits, barriers, community support, and stigma associated with pram walking groups designed for new mothers, Sydney, Australia. Health care for women international, 23(8), pp.882-93.

Cushing, D. F., and van Vliet-, W. 2017. Children's right to the city: the emergence of youth councils in the United States. Children's Geographies, 15(3), 319-333.

Deleuze, G., Guattari, F. and (trans.) Massumi, B., 1987. A Thousand Plateaus, Minneapolis: University of Minnesota Press.

Dowling, R., 2000. Cultures of mothering and car use in suburban Sydney: a preliminary investigation. Geoforum, 31, pp.345-353.

Duffy, M., Waitt, G. and Harada, T., 2016. Making sense of sound: Visceral sonic mapping as a research tool. Emotion, Space and Society, 20, pp.49-57.

Fenster, T., 2005. The Right to the Gendered City: Different Formations of Belonging in Everyday Life. Journal of Gender Studies, 14(3), 217-231. 
Fisher, P., 2002, The vehement passions, Princeton, New Jersey: Princeton University Press.

Fritze, J., 2007. "You might as well just stay at home”: young mums and transport in Victoria, Melbourne: Victorian Council of Social Service. Available at: http://vcoss.org.au/documents/VCOSS docs/Transport/VCOSSYoungMums+Transport LR.pdf.

Gibson, J.J., 1986. The ecological approach to visual perception, Hillsdale, New Jersey: Lawrence Erlbaum Associates (originally published 1979).

Gleeson, B. and Sipe, N., 2006. Creating Child Friendly Cities: reinstating kids in the city, Oxon and New York: Routledge.

Grant-Smith, D., Edwards, P. and Johnson, L., 2012. Mobility in the child (and carer) friendly city: SEQ vs Stockholm. In Association of European Schools of Planning 26th Annual Congress, 11-15 July 2012, Ankara, Turkey. pp. 1-21.

Greig, A., Taylor, J. and MacKay, T., 2007. Doing research with children, London: SAGE Publications.

Harvey, D., 2008. The Right to the City. New Left Review, 53, 23-40.

Hillman, M., Adams, J. and Whitelegg, J., 1990. ONE FALSE MOVE ... A Study of Children’s Independent Mobility, London: Policy Studies Institute.

Hillman, M., Henderson, I. and Whalley, A., 1976. Transport Realities and Planning Policy: Studies of Friction and Freedom in Daily Travel, London: Political and Economic Planning.

Holdsworth, C., 2013. Family and Intimate Mobilities, Basingstoke: Palgrave Macmillan. 
Holloway, S.L. and Valentine, G., 1999. Children's geographies: playing living learning, London: Routledge.

Horton, J., Christensen, P., Kraftl, P., and Hadfield-Hill, S. 2014. "Walking ... just walking": how children and young people's everyday pedestrian practices matter. Social and Cultural Geography, 15(1), pp.94-115.

Horton, J. and Kraftl, P., 2005. For more-than-usefulness: Six overlapping points about Children's Geographies. Children’s Geographies, 3(2), pp.131-143.

Horton, J., Kraftl, P. and Tucker, F., 2008. The challenges of “Children”s Geographies': a reaffirmation. Children's Geographies, 6(4), pp.335-348.

Jensen, O.B., Sheller, M. and Wind, S., 2015. Together and Apart : Affective Ambiences and Negotiation in Families' Everyday Life and Mobility. Mobilities, 10(3), pp.363-382.

Karsten, L., 2005. It all used to be better? Different generations on continuity and change in urban children's daily use of space. Children's Geographies, 3(3), pp.275-290.

Kullman, K., 2010. Transitional geographies: making mobile children. Social and Cultural Geography, 11(8), pp.829-846.

Kytta, M., 2004. The extent of children's independent mobility and the number of actualized affordances as criteria for child-friendly environments. Journal of Environmental Psychology, 24(2), pp.179-198.

Manderscheid, K., 2009. Unequal Mobilities. In T. Ohnmacht, H. Maksim, and M. . Bergman, eds. Mobilities and Inequality. Farnham: Ashgate, pp. 27-50.

MATRIX, 1984. Making Space: Women and the Man Made Environment, Leichhardt, Sydney: Pluto Press. 
McCormack, D.P., 2008. Engineering affective atmospheres on the moving geographies of the 1897 Andree expedition. Cultural Geographies, 15, pp.413-430.

McDonald, N.C. and Aalborg, A.E., 2009. Why Parents Drive Children to School: Implications for Safe Routes to School Programs. Journal of the American Planning Association, 75(3), pp.331-342.

McDowell, L., 1993. Space, place and gender relations: part I. Feminist empiricism and the geography of social relations. Progress in Human Geography, 17(2), pp.157-179.

McLaren, A.T. and Parusel, S., 2015. "Watching like a hawk": gendered parenting in automobilized urban spaces. Gender, Place and Culture, 22(10), pp.1426-1444.

Michael, M., 2000. These boots are made for walking...: Mundane technology, the body and human-environment relations. Body and Society, 6(3-4), pp.107-126.

Middleton, J., 2016. The socialities of everyday urban walking and the 'right to the city. Urban Studies, 1-20.

Mikkelsen, M.R. and Christensen, P., 2009. Is Children's Independent Mobility Really Independent? A Study of Children's Mobility Combining Ethnography and GPS/Mobile Phone Technologies. Mobilities, 4(1), pp.37-58.

Nansen, B., Gibbs, L., MacDougall, C., Vetere, F., Ross, N. J., and McKendrick, J. 2015. Children's interdependent mobility: compositions, collaborations and compromises.

Children’s Geographies, 13(4), 467-481.

Pink, S., 2007. Walking with video. Visual Studies, 22, pp.240-252.

Pink, S., 2009. Doing Sensory Ethnography, London: SAGE Publications. 
Salamon, A., 2015. Ethical symmetry in participatory research with infants. Early Child Development and Care, 185(6), pp.1016-1030.

Schoeppe, S., Tranter, P., Duncan, M. J., Curtis, C., Carver, A., and Malone, K. 2016. Australian children's independent mobility levels: secondary analyses of cross-sectional data between 1991 and 2012. Children's Geographies, 14(4), 408-421.

Spinney, J., 2009. Cycling the city: movement, meaning and method. Geography Compass, 3(2), pp.817-835.

Talbot, D., 2013. Early parenting and the urban experience: Risk, community, play and embodiment in an East London neighbourhood. Children's Geographies, 11(2), pp.230-242.

Tisdall, E.K.M. and Punch, S., 2012. Not so "new"? Looking critically at childhood studies. Children’s Geographies, 10(3), pp.249-264.

Tivers, J., 1985. Women attached: The daily lives of women with young children, New York: St. Martin's Press.

UNICEF, 2004. Building Child Friendly Cities: A Framework for Action, Florence: UNICEF Innocenti Research Centre.

Villanueva, K., Giles-Corti, B., Bulsara, M., Trapp, G., Timperio, A., McCormack, G., and Van Niel, K. 2014. Does the walkability of neighbourhoods affect children's independent mobility, independent of parental, socio-cultural and individual factors? Children's Geographies, 12(4) pp.393-411.

Waitt, G. and Harada, T., 2016. Parenting, care and the family car. Social and Cultural Geography, 17(8), pp.1079-1100. 
Waitt, G., Kerr, S-M. and Klocker, N. 2016. Gender, ethnicity and sustainable mobility: A governmentality analysis of migrant Chinese women's daily trips in Sydney', Applied Mobilities, 1(1), pp. 68-84.

Whitzman, C., Worthington, M., and Mizrachi, D., 2010. The Journey and the Destination Matter: Child-Friendly Cities and Children's Right to the City. Built Environment, 36(4), pp.474-486.

Wollongong City Council, 2015. Children and Family. Available at:

http://www.wollongong.nsw.gov.au/services/community/pages/childrenfamily.aspx [Accessed 12 January 2017].

Wollongong City Council, 2014. Play Wollongong Strategy 2014-2024, Available at: http://www.wollongong.nsw.gov.au/facilities/sportrec/Documents/Play\%20Wollongong\%20 Strategy\%202014-2024.pdf [Accessed 12 January 2017].

Woolcock, G., Gleeson, B., and Randolph, B. 2010. Urban research and child-friendly cities: a new Australian outline. Children's Geographies, 8(2), 177-192.

Woolley, H.E. and Griffin, E., 2015. Decreasing experiences of home range, outdoor spaces, activities and companions: changes across three generations in Sheffield in north England. Children’s Geographies, 13(6), pp.677-691. 


\section{Figures}

Figure 1. Becoming 'grown-up'. Sunni (mid-30s), Madi (age 4) and sister Saffi (age 6) walking to swimming lessons without the pram.

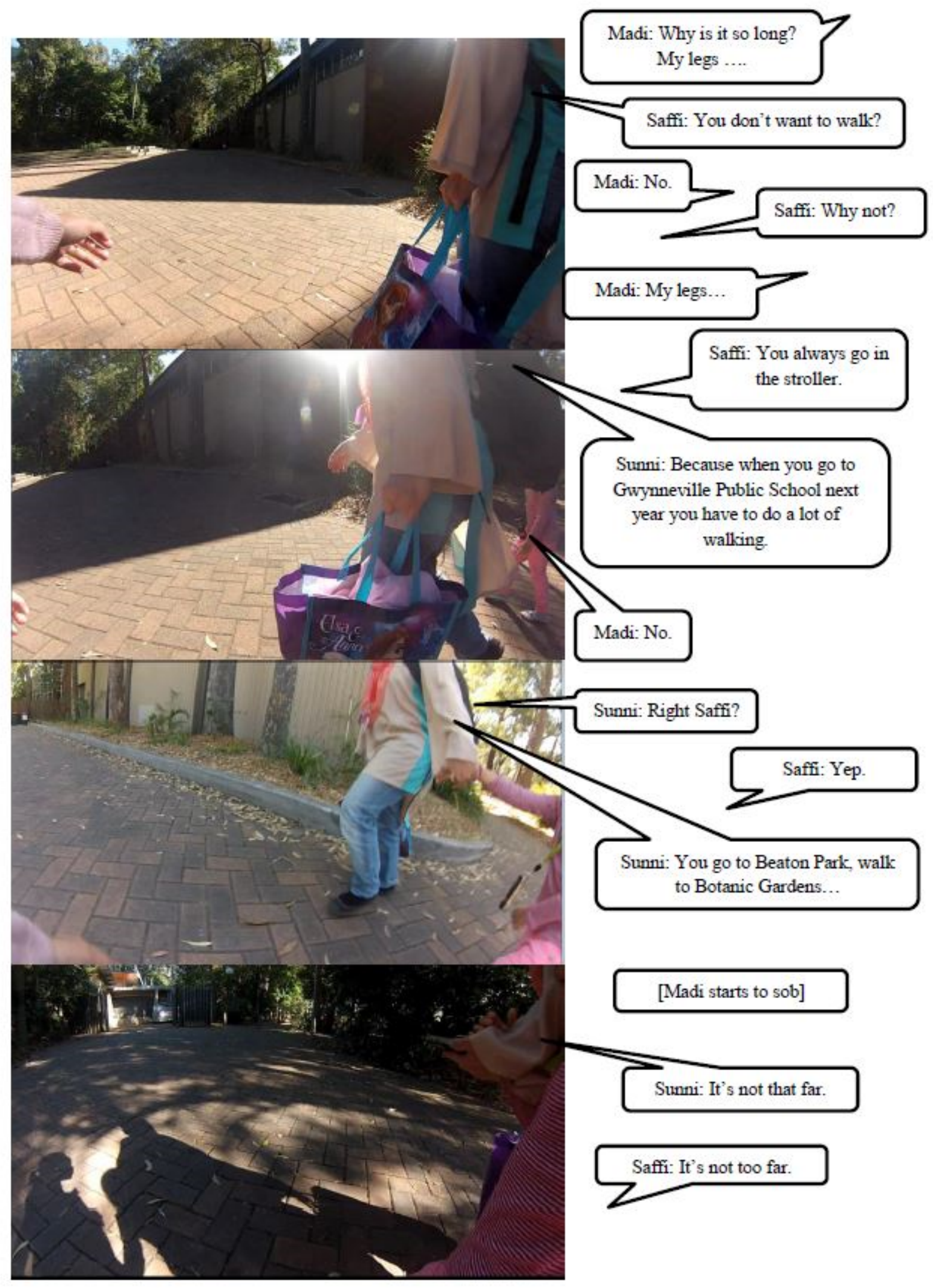


Figure 2. Frustrations. Bella (mid-30s) and Lachlan (age 4) waiting at the traffic lights on the way to Woolworths.

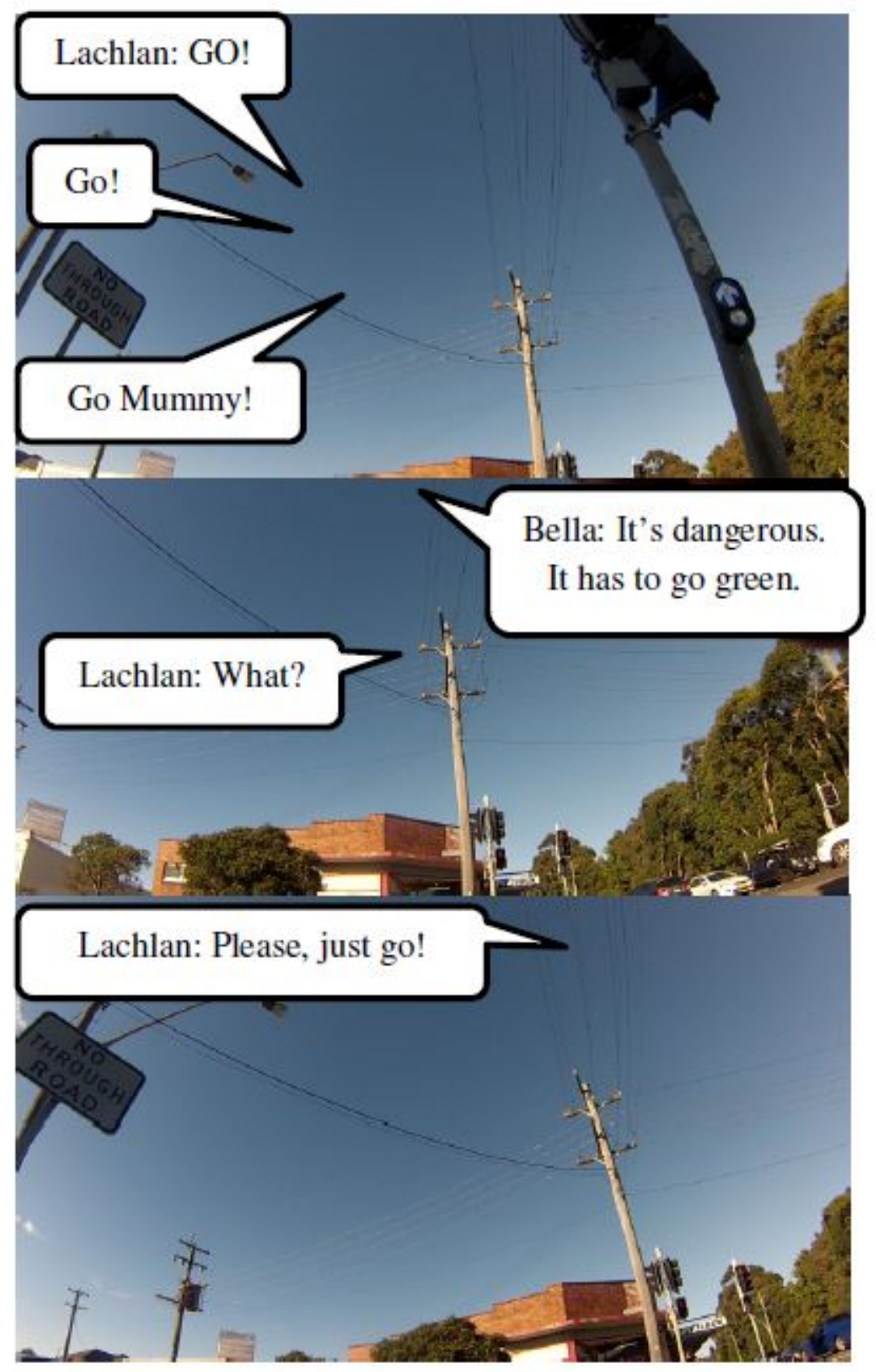


Figure 3. Having fun. Alicia (early 50s) and Ethan (age 3) walking home from a friend's house.

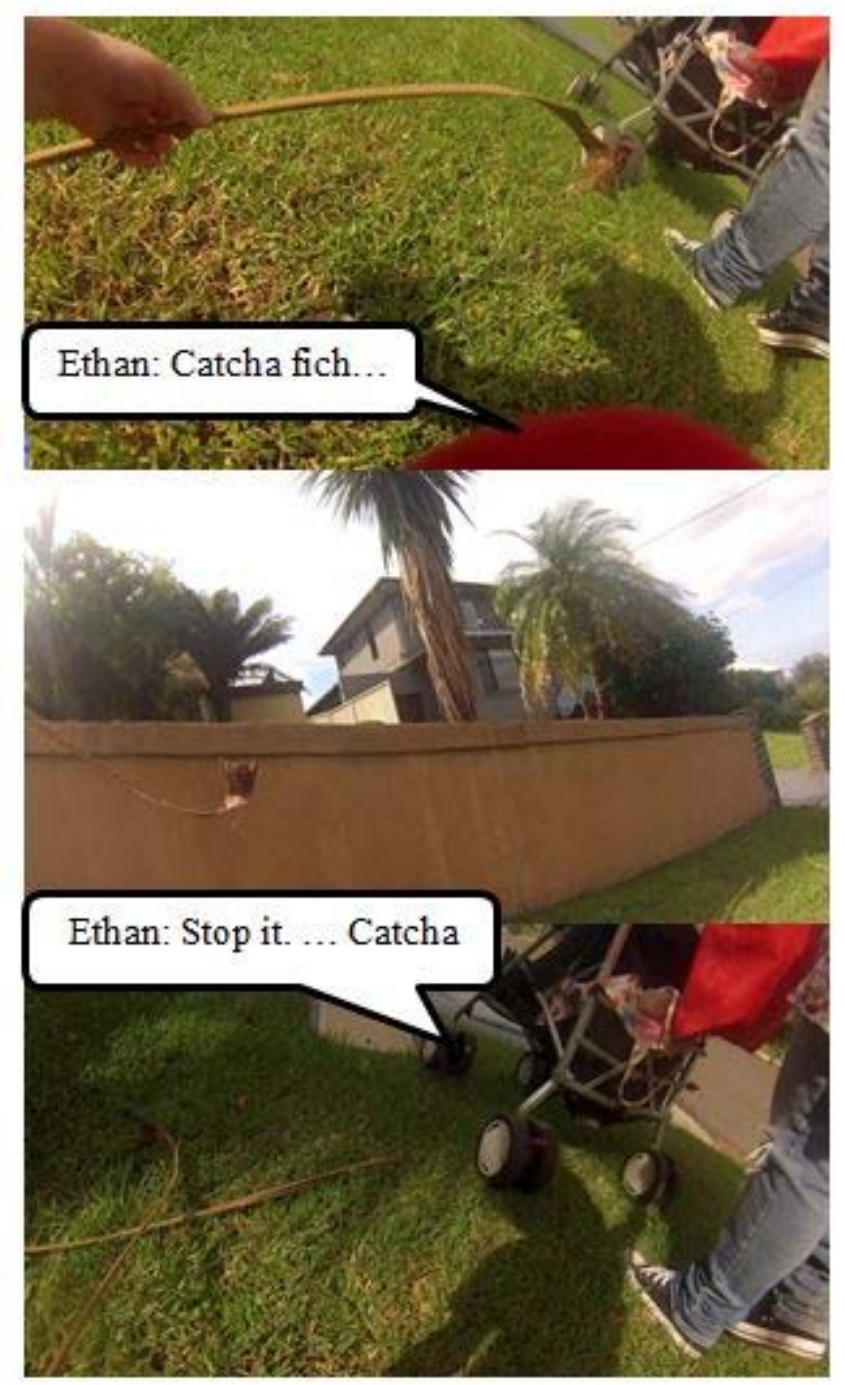

